\title{
Impact of GST on Hotel Industry- A Study in Bhubaneswar City in Odisha
}

\author{
Aditya Prasad Sahoo \\ $\mathrm{PhD}$ Research Scholar, KSOM, KIIT University, \\ Bhubaneswar, Odisha, India, \\ adityasahoo007@gmail.com
}

\author{
Dr. Yajnya Dutta Nayak \\ Assistant Professor, P.G. Department of Commerce \\ Khallikote Auto. College, Berhampur, \\ Odisha, India
}

\begin{abstract}
Three decades later, indirect taxation modifications took place in India on 1 July 2017. Goods and service tax is a uniform indirect tax to be applied across the country for the purpose of a "one nation - one tax." This study seeks to show the effect on the Indian hospitality industry of the goods and services tax. The Indian market is integrated with the introduction of GST and the company costs will be lowered in the foreseeable future. The hotel industry was in burden with multiple taxes on amount charged for different services. Previously, additional charges were charged for different activities in hotel industry in India. But now in GST, single tax charged with clearly stated slab rates for various services. Slab rate increases with increase in number of services charged i.e., for basic services rates are less and luxurious services are under high GST slab rate. Here we try to explain the impact of GST system on hoteliers of Bhubaneswar city. For this purpose, researcher collected samples from 15 hotels of the city. This paper is aimed at assessing the observation and experience of hotel owners after GST in interacting with consumers.
\end{abstract}

\section{Keywords}

GST, Hotel, Customers, Tax, Services

\section{INTRODUCTION}

Goods and Services Tax is an indirect tax which replaced all other indirect taxes in India. GST officially introduced as The Constitution (One Hundred and First Amendment) Act, 2016. This amendment introduced a national Goods and Services Tax (GST) in India from 1st July, 2017. Goods and Services Tax is a comprehensive, multistage, destination-based tax that will be levied on every value addition and at the time of supply of goods and services. "GST offsets the side effects of previous indirect taxes such as cascading effect, high-cost, inefficient tax structure, tax avoidance and evasion, etc., Abraham [1]". GST is levied by both Central and State Government and charged similarly as per their respective shares that shows the transparency in tax structure.

\subsection{Components of GST}

There are three applicable taxes under GST:

a) SGST/UTGST: Collected on an intra- state/union territory sale by the State/Union Territory Government.

b) CGST: Collected on an intra-state/union territory sale by the Central Government.

c) IGST: Collected for inter-state sale by the Central Government
GST slab rates are $0 \%, 5 \%, 12 \%, 18 \%, 28 \%$ and out of which half of share goes to respective State Government and other half to Central Government.

\section{REVIEW OF LITERARUTE}

\subsection{Pandey[10]}

found that comparing to the Asian counterparts, GST rates for hotel industry is higher in India. Japan and Singapore levy a tax rate at $8 \%$ and $7 \%$ respectively in the hospitality sector, which is much less that Indian tax rates. This could result into adverse effects on the business of the hospitality sector of India in the long run.

\subsection{Dr. Meenu Baliyan Punjika Rathi[5]}

concludes that GST will be solving all the complexities present in the current indirect tax system. It is expected that it would give relief to various parties like consumers, producers and Government.

\subsection{Dhanuka[6]}

stated that this decision will benefit consumers and improve the ease of doing business, as hotels will be able to offer upgrades to customers without the fear of charging 28 percent GST.

\subsection{Japee and Lakhani[7]}

focused on impact of GST from international perspective. Researcher presented pre and post GST tax classification and also explained the importance and need of GST in India. This study also explains the journey of GST that how it came into effect in 2017 and also analysis of impact of GST on famous sectors of economy has been done. At last researchers concludes that this tax system will benefit the customers as well as the business houses only when the entire country works as a whole towards making it successful.

\subsection{Sonia Bharwani, David Mathews, Amarpreet Singh Ghura[11]}

The purpose of this study is to examine the factors for the surge of stand-alone hotels and to determine the advantages of outsourcing food and beverage $(\mathrm{F} \& \mathrm{~B})$ in luxury hotels from the standpoints of the proactive participating members in such an industry. The study also proposed different formats for F\&B outsourcing in luxury hotels. To fight the competitive disruption arising because of this trend, the study suggests the business model innovation of outsourcing F\&B operations in luxury hotels. 


\subsection{Saeeda[13]}

studied about GST: Impact of GST on Various Aspects of Restaurant and Hotel Business in Anand and Nadiad District. The main aim of the study is to examine the impact of GST on various aspect of restaurant business in Anand and Nadiad City. For the study purpose, researcher selected 35 hotels and restaurants from Anand city and 33 hotels and restaurants from Nadiad city using Convenience Sampling technique. The study is based on primary data collected using structure questionnaire. Researcher used Pearson Correlation, T-test and Independent sample test for the hypothesis testing. Researcher concluded that even after the implementation of GST, the effect of GST on sales and purchase of hotel and restaurants do not put any effect on profit and the results remain neutral. Researcher also stated that accounting procedure and record keeping become easier and production and service cost remains same.

\subsection{Abraham and Mathew[1]}

examined the GST impact in Kerala on hotel business. The main aim of the study is to examine the views received from hoteliers on the GST execution. A questionnaire was designed and administered to 60 hotels with restaurants across the district of Kottayam for the study using convenience sampling technique. Researchers concluded that the large number of hotel owners have articulated trust in the process, despite the fact that a large number of hotels have sustained added expenses in migrating to the GST system, because they believe that GST will be helpful in the future.

\subsection{Subha and Premkumar[12]}

examined An Empirical Study on Impact of GST on Hotel Industry at Chennai City. The purpose of the study is to determine the impact of GST on the hotel industry in Chennai using five independent variables to categorize consumers' opinions on the GST regime, notably GST is efficacious, simple to comprehend, taxation ailment, cash flow, and increase of consumption after GST. For study purpose researchers collected data from 50 hotels by using structured interview method. The disproportionate stratified simple random sampling technique was used by the researchers. Researchers used descriptive statistics and multiple regression analysis to analyze data. While slashing the GST rates on hotels, the Finance minister Mr. Arun Jaitley was commented that since the hotels did not pass on the ITC benefit to customers, they will not be eligible to avail ITC themselves. This decision of not providing input tax credit to hoteliers was met with much discontent from hoteliers and they stated that the very concept of Input Tax Credit is contradictory to the purpose of introducing GST which is to prevent cascading of taxes. But The latest GST council's decision to levy tax on the transaction value of hotel rooms instead of the declared tariff was welcomed by the hotel industry.

\section{AYE AND NAY OF GST}

\subsection{Aye}

a) GST implementation leads to ease of administration and reduces the workload of the hotel management.

b) GST reduces taxes on hotel bills which lead to attraction of more customers by which revenue increases.

c) Due to transparency in GST system, bill structure is easy to understand for customers as well as for hoteliers.

d) The new structure makes tax avoidance and tax evasion difficult that leads to increase in government revenue.

\subsection{Nay}

a) Initially due to introduction of new tax system, there was a great ambiguity and due to fear of new system still there is less acceptance of the system by various businesses including hotel business.

b) The GST slab rate is very high for luxury hotels as their charges are more comparatively.

c) Either way hotel industry will face the cost increments whether they will go for new skilled employee or providing proper training to the existing one.

\section{GST RATE APPLICABILITY}

Table 1: Applicability of GST rates

\begin{tabular}{|c|c|c|c|}
\hline \multicolumn{4}{|c|}{ GST on Room Tariff } \\
\hline Below 1000 Rs. & $\begin{array}{l}1000 \mathrm{R} \\
\text { Rs. }\end{array}$ & To 7499 & 7500 Rs. Or more \\
\hline $0 \%$ & & $12 \%$ & $18 \%$ \\
\hline \multicolumn{4}{|c|}{ GST on Restaurant } \\
\hline \multicolumn{2}{|c|}{$\begin{array}{l}18 \% \text { on AC restaurants } \\
\text { within hotels }\end{array}$} & \multicolumn{2}{|c|}{$\begin{array}{l}\text { Composition scheme } \\
\text { takeaway is available 5\% }\end{array}$} \\
\hline \multicolumn{2}{|c|}{ GST on Banquets } & \multicolumn{2}{|l|}{$18 \%$} \\
\hline \multicolumn{4}{|c|}{ GST on Other Services } \\
\hline \multicolumn{2}{|c|}{$\begin{array}{l}\text { Doctor on call, Spa, Laundry } \\
-18 \%\end{array}$} & \multicolumn{2}{|c|}{$\begin{array}{lll}\text { Car Rentals, } & \text { Cab, } & \text { etc. } \\
\text { provided by hotels }-5 \% & \end{array}$} \\
\hline
\end{tabular}

\section{RESEARCH METHODOLOGY}

The Hotel Industry is in burdened of taxes at every point i.e., right from the purchase of raw materials till sale of services and goods. GST rates are more on high room tariffs and issue in compliance of GST rates on various services provided by hotels. Hoteliers face difficulties in dealing with GST rates charged to consumers on a variety of services. Another important reason for this study is to stop hoteliers to cheat their clients and on other hand also to examine the problems faced by them in compliance with the system and their perception regarding the GST implementation and its effect on their business. Goods and Services Tax (GST) affected various segments of the economy in India. Hospitality industry is one of the important with highly growth industry of India. Consequently, change in indirect taxation system will have an impact on the industry. This paper highlights the impact of GST on hotel industry and perception of hoteliers after its implementation. For this study the data has been placid from primary source through structure questionnaire. Sample of 15 hotels collected from Bhubaneswar city of Odisha for testing the hypothesis as per convenient sampling method. The data collected were analyzed using chi square test.

\section{OBJECTIVES OF THE STUDY}

- The overall objective of the study is to evaluate the impact of GST on hotel industry.

- To evaluate the customer satisfaction by observing the impact on customers buying behavior.

- This study also aims to analyze the relationship between clarity of customers regarding GST and issues faced by hotelier while handling their customers. 


\section{THE HYPOTHESIS}

\section{$7.1 \mathrm{H1}$}

There is a significant difference exist between satisfaction of customers and buying behavior after implementation of GST.

\section{$7.2 \mathrm{H} 2$}

There is a significant difference exist between Simplicity of Customers concerning GST and handling the problems of customers in hotel industry.

\section{DATA ANALYSIS $8.2 \mathrm{H1}$}

There is a significant difference between satisfaction of customers and buying behavior after implementation of GST.

Table-2: Customer's satisfaction and buying behavior after GST implementation

\begin{tabular}{|l|l|c|c|}
\hline \multicolumn{1}{|c|}{ Parameters } & Value & df & $\begin{array}{l}\text { Asymptotic } \\
\text { Significance } \\
\text { (2-sided) }\end{array}$ \\
\hline Pearson Chi-Square & $11.436 \mathrm{a}$ & 2 & 0.112 \\
\hline Likelihood Ratio & 13.206 & 2 & 0.221 \\
\hline $\begin{array}{l}\text { Linear-by-Linear } \\
\text { Association }\end{array}$ & 8.721 & 1 & 0.202 \\
\hline N of Valid Cases & 15 & & \\
\hline
\end{tabular}

Source: Author's Calculation, Sig. Level: 0.05

In the Table 1, It can be seen that the Pearson Chi-Sqaure value is .112 which is more than the level of significance 0.05 . Therefore, we are accepting the hypothesis H1 that there is a significant difference exists between satisfaction of customers and their buying behavior after GST implementation. In other means both customer's satisfaction and their buying behavior were affected by the GST implementation in the study.

\section{$8.3 \mathrm{H} 2$}

There is a significant difference exist between Simplicity of Customers concerning GST and handling their problems after GST implementation.

Table-3: Simplicity and handling of customers problem in hotel industry

\begin{tabular}{|l|l|c|c|}
\hline \multicolumn{1}{|c|}{ Parameters } & Value & df & $\begin{array}{l}\text { Asymptotic } \\
\text { Significance } \\
\text { (2-sided) }\end{array}$ \\
\hline Pearson Chi-Square & $11.339 \mathrm{a}$ & 2 & 0.212 \\
\hline Likelihood Ratio & 13.115 & 2 & 0.131 \\
\hline $\begin{array}{l}\text { Linear-by-Linear } \\
\text { Association }\end{array}$ & 7.920 & 1 & 0.229 \\
\hline \multicolumn{1}{|c|}{ N of Valid Cases } & 15 & & \\
\hline
\end{tabular}

Source: Author's Calculation, Sig. Level: 0.05

In the Table 2, It can be seen that the Pearson Chi-Sqaure value is .212. This is more than the level of significance 0.05 . Therefore, we are accepting the hypothesis $\mathrm{H} 2$ that there is a significant difference exists between simplicity of customers concerning GST and handling their problems after GST implementation. In other means both customer's simplicity as well as handling their problems were affected by the GST implementation in the study.

\section{CONCLUSION}

Hotels are benefited in food and beverages area and also this system is beneficial for budget hotels which are under slab rate of $12 \%$. But hotels that comes beneath the slab rate of 18 to 28 percent facing hostile effect due to the GST. With the above objectives determined, we can conclude that there is significance relationship between level of customer satisfaction and change in their buying behavior after implementation of GST in hotel industry. There is a clarification of customers regarding GST rates and the amount paid by them as GST towards the services received in hotels. There is a significance relationship between the clarity customers having about GST rates in hotel industry and issues faced by hoteliers in handling their customers. Increasing the consumer consumption of consumers will put positive impact on government revenue and at the same time increases the job prospects in hotel industry. With this positive impact, hoteliers facing some issues financially while dealing with their customers.

\section{REFERENCES}

[1] Abraham, A., \& Dr. Mathew, T. (2019) A Study on the Impact of Goods and Services Tax Reform on Hotels in Kerala. International Journal of Management Studies, 6(1), 54-61.

[2] Akshay R. Rakhunde, Dr. Priti Rai. (2019) Effect of GST in Hotel Industry (Nagpur). International Journal of Scientific Research in Engineering and Management (IJSREM), 3(10), $1-7$.

[3] Aswathy Krishna \& Divya. M.S, Aashish C.I (2018) A study on GST and its effect on hotel industry. IOSR Journal of Business and Management (IOSR-JBM), 4-5.

[4] Bhat, S. a. (2018). A study on the problems of Goods and Services Tax on Hotel Industry in Mysore District. Journal of Business and Management-IOSR, 49-52.

[5] Dr. Meenu Baliyan Punjika Rathi (2018) Impact of GST On Different Sectors of Indian Economy, International Journal of Innovative Research and Advanced Studies (IJIRAS) Volume 5 Issue 3, March 2018, ISSN: 2394-4404.

[6] Dhanuka, Saloni. (2018, July 23). GST: Hotel Industry Lauds GST Relief but Divided on Impact. Bloomberg Quint.

[7] Japee and Lakhani (2018) Goods and Services Tax in India: Paradigm Change in Taxation, International Journal for Research in Applied Science \& Engineering Technology (IJRASET), Volume 6 Issue I, ISSN: 2321-9653.

[8] Panwar, D \& Patra, S. (2019) Impact of Goods and Services Tax on the Restaurants and Food Service Businesses in India. International Journal of Applied Business and Economic Research, 15(23), 203-213.

[9] Patra, D. P. (2017). Impact of Goods and Services Tax on the Restaurants and Food service Businesses in India International Journal of Applied Business and Economic Research, 203-213.

[10] Pandey, Sony. Impact of GST on Hospitality Industry. Retrieved from https://www.hrblock.in/blog/impact-gsthospitality-industry, October 2017.

[11] Sonia Bharwani, David Mathews, Amarpreet Singh Ghura (2019) Business model innovation in the Indian hospitality industry: A study of the willingness to outsource specialty 


\section{Impact of GST on Hotel Industry- A Study in Bhubaneswar City in Odisha}

restaurants in luxury hotels, Worldwide Hospitality and Tourism Themes, ISSN: 1755-4217

[12] Subha and Premkumar (2020) An Empirical Study on Impact of GST on Hotel Industry at Chennai City, Journal of Emerging Technologies an Innovative Research, Volume 7, Issue-2, Pg. 106-110.
[13] Saeeda, F. A. (2019). GST: Impact of GST on Various Aspects of Restaurants and Hotel Business in Anand and Nadiad District. Journal of Information and Computational Science, 352-358. 